\title{
Refuge
}

Canada's Journal on Refugees

revue canadienne sur les réfugiés

\section{Introduction: The Racialized Refugee Regime}

\section{Christopher Kyriakides, Dina Taha, Carlo Handy Charles and Rodolfo D. Torres}

Volume 35, Number 1, 2019

Racialized Refuge

URI: https://id.erudit.org/iderudit/1060670ar

DOI: https://doi.org/10.7202/1060670ar

See table of contents

Publisher(s)

Centre for Refugee Studies, York University

ISSN

0229-5113 (print)

1920-7336 (digital)

Explore this journal

Cite this document

Kyriakides, C., Taha, D., Charles, C. \& Torres, R. (2019). Introduction: The

Racialized Refugee Regime. Refuge, 35(1), 3-7. https://doi.org/10.7202/1060670ar

Copyright (c) Refuge: Canada's Journal on Refugees, 2019

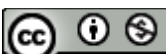

This document is protected by copyright law. Use of the services of Érudit (including reproduction) is subject to its terms and conditions, which can be viewed online.

https://apropos.erudit.org/en/users/policy-on-use/ 


\title{
Introduction: The Racialized Refugee Regime
}

\author{
CHRISTOPHER KYRIAKIDES, DINA TAHA, CARLO HANDY CHARLES, and RODOLFO D. TORRES
}

$\mathrm{T}$ The Racialized Reception Contexts (RRC) research program was launched at conference at York University in October 2016. The conference featured twenty-three speakers, including established and emerging scholars from ten countries, each of whom was concerned to draw a deeper connection between scholarship in refugee studies (Rs) and ethnic and racial studies (ERs). This special issue is the first of two RRC general publications that aim to give an explicit platform for the further development of that connection. ${ }^{1}$

At its onset, RRC sought to draw from ERs the insight that "race" is a social construct rather than a "biological fact," but also that it be considered more than a variable that may or may not be relevant to Rs scholars, depending on the particular group that was/is being subject to refuge. In what is increasingly referred to as the Global Refugee Regime, "persecution on the grounds of race" is but one of many on which a person might legitimately make a claim for asylum. In this respect, the concept of racialization is helpful in that it can refer to the "signification of some biological characteristic(s) as the criterion by which a collectivity may be identified.... [T] he collectivity is represented as having a natural, unchanging origin and status, and therefore as being inherently different." ${ }^{2}$ Yet ERs scholars have long recognized that racialization is an embedded structure of oppression with deep roots within capitalist modernity and the world economy. ${ }^{3}$ Indeed, the institutional context that prefigured the twentieth-century concern with refugees-the League of Nations early inauguration of the first high commissioner

(c) C. Kyriakides, D. Taha, C.H. Charles, and R.D. Torres, 2019. This open-access work is licensed under a Creative Commons Attribution-NonCommercial 4.0 International Licence, which permits use, reproduction, and distribution in any medium for non-commercial purposes, provided the original authorship is credited and the original publication in Refuge: Canada's Journal on Refugees is cited. for refugees in 1919-was paralleled by the rejection of the Racial Equality Proposal, which had been tabled as an amendment to the Covenant of the League of Nations by one of the league's founding great powers, Japan. The rejected proposal read: "The equality of nations being a basic principle of the League of Nations, the High Contracting Parties agree to accord as soon as possible to all alien nationals of states, members of the League, equal and just treatment in every respect making no distinction, either in law or in fact, on account of their race or nationality." 4

The Racial Equality Proposal had cast a spotlight on the connections between racialized oppression in the domestic contexts of Western powers, their empires, and imperialist rivalries, and had enjoyed fervent support, particularly among Blacks in the United States. As Kearney notes, "There developed a great enthusiasm in the black communities of the United States for a Japan-led, anti-white-imperialist movement." 5 The league's rejection of racial equality in international relations was due in part to the emerging concern to divest domestic demands for racial equality and anti-racist resistance of political authority; that is, to depoliticize what $\mathrm{Du}$ Bois had referred to as "the problem of the twentieth century ... the problem of the color-line." The depoliticization of race in international relations could not be so easily accomplished when faced by the anti-colonial movements of the pre- and post-Second World War period, and potently, in the aftermath of the Third Reich's promotion of scientific racism as ideological justification for the annihilation of six

Cette œuvre en libre accès fait l'objet d'une licence Creative Commons Attribution-NonCommercial 4.o International License, laquelle autorise l'utilisation, la reproduction et la distribution de l'œuvre sur tout support à des fins non commerciales, pourvu que l'auteur ou les auteurs originaux soient mentionnés et que la publication originale dans Refuge: revue canadienne sur les réfugiés soit citée. 
million Jews. Reflecting on three trips to Poland after the war, Du Bois drew out the interconnections between racialization as a global process and the particularities of racialization as pertaining to different groups:

The result of these three visits, and particularly of my view of the Warsaw ghetto, was not so much clearer understanding of the Jewish problem in the world as it was a real and complete understanding of the Negro problem. In the first place, the problem of slavery, emancipation and caste in the United States was no longer in my mind a separate and unique thing as I had so long conceived it. It was not even solely a matter of color and physical and racial characteristics, which was particularly a hard thing for me to learn, since for a lifetime the color line had been a real and efficient cause of misery. ${ }^{7}$

In 1950 the United Nations Educational, Scientific and Cultural Organisation (UNESCO) issued the first of what would subsequently become known as its Four Statements on Race. ${ }^{8}$ The 1950 statement, and its three revisions in 1951, 1964, and 1967, embodied the rationale underpinning the establishment of UNESCO in 1945-to respond, in the aftermath of the Second World War, to the barbarism and atrocities committed, uninhibited in a moral climate validated by scientific racism: "The great and terrible war, which has now ended, was a war made possible by the denial of the democratic principles of the dignity, equality and mutual respect of men, and by the propagation, in their place, through ignorance and prejudice, of the doctrine of the inequality of men and races."

As stated in UNESCo's founding constitution, its organizational purpose and remit was "to contribute to peace and security by promoting collaboration among the nations through education, science and culture in order to further universal respect for justice, for the rule of law and for the human rights and fundamental freedoms which are affirmed for the peoples of the world, without distinction of race, sex, language or religion, by the Charter of the United Nations."

The significance of UNEsco's first Statement on Race is that it issued a counter-narrative against the idea that human beings can be legitimately categorized and subsequently evaluated individually and socially as members of biologically distinct racial groups or types; that is, "historical and sociological studies support the view that genetic differences are not of importance in determining the social and cultural differences between different groups of homo-sapiens, and that the social and cultural changes in different groups have, in the main, been independent of changes in inborn constitution. Vast social changes have occurred which were not in any way connected with changes in racial type."
UNESCO's objective of challenging "the myth of race" by distinguishing it from "the biological fact of race" 10 sought to create distance from the nineteenth-century imperialist nationalist view encapsulated in Victorian Tory politician Benjamin Disraeli's espoused doctrine that "all is race." The belief that humans could be categorized as belonging to one of three biologically constituted and unchanging groups-Caucasoid, Negroid, and Mongoloid - and that cultural, social, and individual characteristics were hierarchically reflective of these "racial types," was such a deeply held view in European and North American societies that it had provided legitimacy for Western nation-building, imperial domination, and the racial extermination policies of the Third Reich. "Race" had the effect of dehumanizing and objectifying people as less deserving of treatment as the human bearers of civilization. The human will to determine one's life trajectory was delimited by racial group belonging. Biology placed agency beyond human hands and into the material object of racial bodies. Yet, and for our purposes, while unEsco challenged the kernel of scientific racism, "race" was positioned as a singular variable not deeply constitutive of the intimate and racializing relationship between geopolitics and the domestic sphere of national reception that positions, grants status to, and ultimately receives refugees.

For UNESCO, ethnicity and culture were more legitimate markers of individual and social characteristics than race. However, unEsco's first Statement on Race did not dislodge the scientifically designated "biological fact of race." The limitation of this approach was that the doctrine of race had emerged and been so interwoven with biological determinacy in the late nineteenth and early twentieth centuries that the fixity connoted by "biological fact" could now be carried by "cultural fact," even when the concept of race was absent from discourse. In short, cultural and ethnic differentiation and fixity could easily become a homologue of race, especially where phenotype (i.e., skin colour) demarcated group belonging: in effect, the logic of racialization shifted to accommodate the view that human beings cannot be categorized by race in a race hierarchy, but by culture in a cultural hierarchy. It is here that overlap with the politics of refuge becomes most explicit.

Scholars working in refugee studies recognize that persons receiving refugee status must navigate the everyday terrain of "refugeeness," 11 a contested condition of existence in which the figure of the refugee is constructed by policy practices ${ }^{12}$ and media representations ${ }^{13}$ that together constitute a media-policy-migration nexus. ${ }^{14} \mathrm{~A}$ set of political and media-validated scripts play out-particularly in the cultural construction of a war-induced "refugee crisis" - that informs Western assumptions of what a refugee is ${ }^{15}$ and that 
excludes the "non-deserving." ${ }^{16}$ In the West, migrants and refugees from the Global South and East are (in)validated within a "victim-pariah" representational status couplet, where entrants must prove they do not constitute a threat to the receiving state. There follows a publicly anticipated performance of the refugee role informed by understandings of war, violence, and their impact on persons displaced by conflict. The performative expectations of contemporary refuge construct refugees as involuntary, non-wilful objects shaped and moved by forces of conflict: "refugees" must fit the "victim" role in order to gain entry, and act so as to retain host acceptance. In the cultural script of refuge, refugees are victims who "deserve" rescue; receiving societies are saviours who provide it.

The construction of "the refugee" as a "forced" "nonWestern" object without will or socio-cultural history, to be rescued by the benevolent West is the central point of overlap between racialization and refuge in the contemporary context of refugee reception. Edward Said's Orientalism thesis offers a partial way into deconstructing cultural scripts of refuge. The Western historical construction of the "non-Western other" as uncivilized, unruly, and lacking in cultural sophistication contrasts with "the West," where the cultivation of self assumes a superior and dominant vantage point from which Western imperial interventions are justified. The West (self) is constructed as active (masculine), knowledgeable, and moral; the East (other) as passive (feminine), to be led by Western virtue. In the macro-context of East-West geopolitics, self-determination movements and anti-colonial struggles of the twentieth century broke "the principle of confinement"17 and were interpreted through the Western lens of unruly barbarity. ${ }^{18}$ Yet, as a considerable body of scholarship has demonstrated, the activities of "displaced persons" cannot be understood as orientated around a conflict-induced "bare life" existence-a universal condition devoid of "pre-conflict" historical and cultural practices. ${ }^{19}$ The pre-conflict identities and behaviours of refugees are affected, but not omitted or defined by conflict and war. Framing refugees as victims "with no histories" whose existence "merely starts with the war" 20 silences the interactive contestation that pre-conflict histories and cultural practices potentially mobilize against the media and policy scripts that currently underpin reception in Western states.

Given the centrality of racialization to geopolitics and the inauguration of the central institutions of international affairs in the twentieth century, to think of "race" as but one of many variables in what can also be called the century of the refugee is somewhat myopic. In short, to refer to the geopolitics of refuge as a "Global Refugee Regime" unwittingly falls into the trap of missing the centrality of racialization as an embedded system of oppression in the West, and to which we offer the counter-designation-the Racialized Refugee Regime.

Each of the articles featured in this special issue grapples with the Racialized Refugee Regime. "Race" is not thought of as a discreet variable for consideration but as part of an embedded structure of oppression in which the racialized refugee regime is generated and reproduced.

In "Forensic Age Estimation in Swiss Asylum Procedures: Race in the Production of Age," Johannes Oertli examines the procedure of forensic age estimation (FAE) used to assess the "actual" age of an unaccompanied young person's claim to be a child. Focusing on Swiss FAE asylum procedures, Oertli unpacks assumptions and practices that lead to "age disputes." The study elaborates on what triggers such "age disputes," highlighting the difference between forensic and medical age estimation and how the use of FAE in a forensic environment racializes the children involved. The piece makes a significant contribution to our understanding of how the putatively scientifically neutral practice of FAE can reproduce ethno-racialized boundaries and legal borders within current refugee regimes.

In "The Borders of Tropicality" Julián Gutiérrez Castaño argues that the discourse of tropicality in Colombia creates boundaries and binaries between racialized and normative territories, rural peripheral areas and urban centres, and spaces. Tropicality constructs darker "barbaric" regions closer to sea level and whiter "civilized" regions in temperate altitudes. The article helps us to move beyond the assumptions underpinning any notion that displacement "contained" within what is usually referred to as the "Global South" is not subject to racialization. Rather, race is a social construct that is in the making permanently, while presenting changes in space and time, challenging any static ideas of racialized refuge in intersection with geography. Yet, while the discourse of tropicality produces racialized spaces, where the process of displacement implies the crossing of the "border" between the "tropics" and the cities, Afro-Colombians, Indigenous people, and mestiza campesinas challenge the ideas of tropicality by creating new geographies as they settle after displacement. The study highlights the importance of understanding agency and the subjective negotiation of racialized refuge by its targets.

In "Queer Credibility in the Homonation State: Interrogating the Affective Impacts of Credibility Assessments on Racialized Sexual Minority Refugee Claimants," Jen Rinaldi and Shanti Fernando critically appraise Canadian Immigration and Refugee Board (IRB) decision-making and argue that the process imposes burdens on diverse sexual orientation and gender identity and expression (sogIE) refugee claimants of colour to prove that they are queer according to homonationalist interpretations of queerness. The article 
makes an important contribution to our understanding of how nationalist refugee reception practices can accommodate ideas that are putatively taken as "progressive" and "anti-oppressive." Their interrogation of legal discourses on "authentic queer refugeeness" reveals how such attributions attached to persons who are socially, politically, and legally organized by the racialized refugee regime can force them to conform to white Western ideals.

In "Patrouille des frontières nationales et représentations racialisées: Analyse de commentaires en ligne sur les réfugiés syriens au Québec" Mathieu Forcier analyzes commentary on the Facebook pages of Quebec's largest media outlets on the Canadian government's plan to resettle Syrian refugees in 2015. The study interrogates the particular configuration of normalized, national belonging used by anxious white ethnic majorities who perceive themselves as threatened by refugee resettlement. New social media therefore create an anomalous status-labelling space through which refugees and the receiving society are racialized as antithetical constituencies. The analysis underscores the fact that the denial of racism and the positive presentation of self were evident in negative discursive framings of the arrival of Syrian refugees. However, the representation of the Quebecois white ethnic majority as a "people" victimized by multicultural elites serves as an important reminder that the racialized exclusion of refugees can operate without recourse to overtly racist language.

In "The 'Worthy' Refugee: Cash as a Diagnostic of 'XenoRacism' and 'Biolegitimacy," Clayton Boeyink argues that the refugee regime represents a racist colonial genealogy in discourse and structure, but also reflects changing geopolitical dynamics that applies a framework of preference to specific groups. The policy of refugee cash transfers, argues Boeyink, represents a biopolitical diagnostic for where refugees are deemed worthy to reside. The article highlights continuity, change, and differential treatment by examining cash for repatriation at the end of the Cold War; cash for urban Iraqi refugees in Jordan following the second Gulf War; and the Tanzanian government's recent decision to shut down a cash project in Nyarugusu refugee camp. Where cash is allowed to flow is dependent on a racialized hierarchy of deserving, which positions the respective statuses of "refugee groups" within the racialized refugee regime.

Paloma E. Villegas and Tanya Aberman's "A Double Punishment: The Context of Post-secondary Access for Racialized Precarious Status Migrant Students in Canada" highlights an important intervention they carried out in a bid to counter the racialized exclusion of "precarious status migrant youth" in post-secondary education. While there are access policies at the primary and secondary school level, racialized barriers in post-secondary education, perpetuated by the immigration and schooling systems in Canada, affect those of refugees in distinctive ways. Drawing from semi-structured interviews with migrant and refugee youth and their own experience organizing an access program at York University that targets precarious status students for inclusion, they indicate that precarious status students transitioning to university experience a "double punishment" through racialized exclusion. They end with a proposal to Canadian universities and policymakers to take head of the findings of their and other interventions so as to increase equitable inclusion.

Each of the articles included in this special issue helps to stimulate a more sensitive and productive understanding of the intimate relationship between racialization and refugee regimes. "Racialized Refuge" is a small step in stimulating wider and deeper debate, a call to think outside of wellestablished narratives, and to develop interventions that tackle the complexities of the Racialized Refugee Regime.

\section{Notes}

1 The second publication is a volume of country case studies, edited by Kyriakides and Torres, to be published by Routledge (Us) in 2020.

2 Robert Miles, Racism (London: Routledge, 1989), 79.

3 For a robust discussion of racialization see Karim Murji and John Solomos, eds., Racialization: Studies in Theory and Practice (Oxford: Oxford University Press, 2005).

4 Cited in Paul Gordon Lauren, Power and Prejudice: The Politics and Diplomacy of Racial Discrimination (London: Routledge, 2018), 92.

5 Reginald Kearney, "Japan: Ally in the Struggle against Racism, 1919-1927," Contributions in Black Studies 12, no. 1 (1994): 120.

6 "The Problem of the Twentieth Century ... The Problem of the Colour Line" is cited in Peter Fryer, ed., Staying Power: The History of Black People in Britain (Edmonton: University of Alberta Press, 1984), 85.

7 W. E. B. Du Bois, “The Negro and the Warsaw Ghetto," Jewish Life, 1952, reprinted in The Social Theory of W. E. B. Du Bois, ed. Phil Zuckerman, 45-6 (Thousand Oaks, CA: Pine Forge, 2004).

8 Unesco, "Four Statements on the Race Question" (Paris: UNESCO, 1969).

9 UNESCO, "Four Statements," 34.

10 UNESCO, "Four Statements," 33.

11 Pauline Brücker, "Voicing Refugeeness: Sudanese Struggles for Belonging in Egypt and Israel," Égypte/Monde arabe 1, no. 15 (2017): 95-123; Stephen Dobson, Cultures of Exile and the Experience of Refugeeness (New York: Peter Lang. Lacroix, Marie. 2004); Marie Lacroix, "Canadian Refugee Policy and the Social Construction of the Refugee Claimant Subjectivity: Understanding Refugeeness," Journal of Refugee Studies 17, no. 2 (2004): 147-66; Edward Ou Jin 
Lee and Brotman Shari, "Identity, Refugeeness, Belonging: Experiences of Sexual Minority Refugees in Canada," Canadian Review of Sociology 48, no. 3 (2011): 241-74; Liisa H. Malkki, "Speechless Emissaries: Refugees, Humanitarianism, and Dehistoricization," Cultural Anthropology 11, no. 3 (1996): 377-404; Joke Schrijvers, "Fighters, Victims and Survivors: Constructions of Ethnicity, Gender and Refugeeness among Tamils in Sri Lanka, Journal of Refugee Studies 12, no. 3 (1999): 307-33; Alice Szczepanikova, "Performing Refugeeness in the Czech Republic: Gendered Depoliticisation through NGo Assistance," Gender, Place \& Culture 17, no. 4 (2010): 461-77.

12 Roger Zetter, "More Labels, Fewer Refugees: Remaking the Refugee Label in an Era of Globalization," Journal of Refugee Studies 20, no. 2 (2007): 172-92.

13 Greg Philo, Emma Briant, and Pauline Donald, Bad News for Refugees (London: Pluto, 2013).

14 Christopher Kyriakides, "Words Don't Come Easy: Al Jazeera's Migrant-Refugee Distinction and the European Culture of (Mis)Trust," Current Sociology 65, no. 7 (2017): 933-52.

15 Stephen C. Lubkemann, Culture in Chaos: An Anthropology of the Social Condition in War (Chicago: University of Chicago Press, 2010).

16 Kyriakides, "Words Don't Come Easy."

17 Edward Said, Culture and Imperialism (New York: Vintage, 1994), 327.

18 Edward Said, Orientalism: Western Conceptions of the Orient (Harmondsworth, UK: Penguin, 1995): 329-52.

19 Ruth M. Krulfeld, "Buddhism, Maintenance and Change: Reinterpreting Gender in a Lao Refugee Community," in Reconstructing Lives, Recapturing Meaning: Refugee Identity,
Gender, and Culture, ed. Linda A. Camino and Ruth M. Krulfeld, 97-127 (New York: Gordon and Breach Publishers, 1994); Simon Turner, "What Is a Refugee Camp? Explorations of the Limits and Effects of the Camp," Journal of Refugee Studies 29, no. 2 (2015): 139-48; Mats Utas, "Victimcy, Girlfriending, Soldiering: Tactic Agency in a Young Woman's Social Navigation of the Liberian War Zone," Anthropological Quarterly 78, no. 2 (2005): 403-30.

20 Christopher Kyriakides, Lubna Bajjali, Arthur McLuhan, and Karen Anderson, "Beyond Refuge: Contested Orientalism and Persons of Self-Rescue," Canadian Ethnic Studies 50, no. 2 (2018): 59-78; Christopher Kyriakides, Arthur McLuhan, Karen Anderson, and Lubna Bajjali, "Status Eligibilities: The Eligibility to Exist and Authority to Act in Refugee-Host Relations," Social Forces, November 3, 2018, https://doi.org/10.1093/sf/soy109.

Christopher Kyriakides holds the Canada Research Chair in Citizenship, Social Justice and Ethno-Racialization, York University,Canada.ckyriak@yorku.ca

Dina Taha is a Ph.D candidate, Department of Sociology, York University, Canada.dinataha@yorku.ca

Carlo Handy Charles is a Ph.D. student, Department of Sociology, McMaster University and the Department of Geography, Université des Antilles.charlc6@mcmaster.ca

Rodolfo D. Torres is professor of urban planning, public policy, and political science, University of California, Irvine.rodolf@ uci.edu 